Article

\title{
Identification of Restricting Parameters on Steps toward the Intermediate-Temperature Planar Solid Oxide Fuel Cell
}

\author{
Yongqing Wang ${ }^{1}\left(\mathbb{D}\right.$, Bo An ${ }^{2,3}$, Ke Wang ${ }^{2,3, * \mathbb{D}}$, Yan Cao ${ }^{4, *}$ and Fan Gao ${ }^{1,3}$ \\ 1 School of Mechanical and Power Engineering, Zhengzhou University, Zhengzhou 450001, China; \\ wangyq@zzu.edu.cn (Y.W.); 202012202013876@gs.zzu.edu.cn (F.G.) \\ 2 School of Mechanics and Safety Engineering, Zhengzhou University, Zhengzhou 450001, China; \\ boan@gs.zzu.edu.cn \\ 3 Key Laboratory of Process Heat Transfer and Energy Saving of Henan Province, Zhengzhou 450001, China \\ 4 Guangzhou Institute of Energy Conversion, Chinese Academy of Sciences, Guangzhou 510640, China \\ * Correspondence: kewang@zzu.edu.cn (K.W.); caoyan@ms.giec.ac.cn (Y.C.); Tel.: +86-371-63887312 (K.W.)
}

Received: 31 October 2020; Accepted: 1 December 2020; Published: 4 December 2020

\begin{abstract}
To identify critical parameters upon variable operational temperatures in a planar SOFC, an experimentally agreeable model was established. The significance of temperature effect on the performance of SOFC components was investigated, and the effect of activation energy during the development of intermediate electrode materials was evaluated. It is found the ionic conductivity of electrolytes is identified to be unavoidably concerned in the development of the intermediate-temperature SOFC. The drop of the ionic conductivity of the electrolyte decreases the overall current density $63 \%$ and $80 \%$ at temperatures reducing to $700{ }^{\circ} \mathrm{C}$ and $650{ }^{\circ} \mathrm{C}$ from $800^{\circ} \mathrm{C}$. However, there exists a critical value on the defined ratio between the electric resistance of the electrolyte in the overall internal resistance of SOFC, above which the further increase in the ionic conductivity would not significantly improve the performance. The lower the operational temperature, the higher critical ratio of the electrical resistance in the overall internal resistance of the cell. The minimal decrease in the activation energy during the development of intermediate electrode materials can significantly enhance the overall performance. Considering the development trend toward the intermediate temperature SOFC, advanced electrode material with the decreased activation energy should be primarily focused. The result provides a guidance reference for developing SOFC with the operational temperature toward the intermediate temperature.
\end{abstract}

Keywords: SOFC; intermediate temperature; electrolytes; electrodes; ionic conductivity; activation energy; dominating factors

\section{Introduction}

Fuel cell (FC) converts storable fossil fuels into instantly usable electricity in a higher efficiency and with $\mathrm{CO}_{2}$ capture ready [1], and also is attractive due to less energy losses during its energy conversion process [2]. The solid oxide fuel cell (SOFC) is one of the fuel cells family and converts chemical energy directly into electrical energy [3], resulting in considerable attention in both its engineering fabrications and theoretic modeling that provides the in-depth mechanical and practical insights for its speed-up development [4]. Among them, the planar-design SOFC is simple in its fabrication and more flexible in its cell geometry and gas manifolding [5]. The SOFC generally operate under elevated temperatures (typically $800^{\circ} \mathrm{C}$ ), resulting in considerable concerns on the durability of its electrode and electrolyte materials and further its higher costs in manufacturing and operation. Higher operational temperatures also make start-up and shutdown longer, less applicable in portable power and transportation markets, and less flexible in practical situations. These key technical issues addressed the critical demands on 
scientific and engineering research breakthroughs in balance parameters and performance of SOFC and the development of advanced materials.

The operation temperature of SOFC has to mainly equilibrate two opposing factors. One is a higher temperature favoring for an increased rate in the oxygen incorporation, reduction, and ionic conductivity, and the other is a lower temperature favoring for the chemical and mechanical durability and the rapidness of the expansion-contraction cycle. Therefore, all aspects addressed on the highest efficiency and durability of the cathode-electrolyte-anode combination at the lowest possible temperatures. This inspired the current considerable progress in searching and making proper material candidates for a shift of the higher operational temperature $\left(800^{\circ} \mathrm{C}-850{ }^{\circ} \mathrm{C}\right)$ down to an intermediate temperature (such as $600^{\circ} \mathrm{C}-650^{\circ} \mathrm{C}$ ) [1]. Practical development involved the use of electrolyte materials of high ionic conductivity and the decrease of electrolyte thickness [6,7]. The perovskite-type metal oxides are traditional materials in the cathode-electrolyte-anode combination with the mobile oxygen vacancy [8,9], showing the promising ionic conductivity, structural rigidness, simple preparation, and excellent match with each other, such as $\mathrm{LSMs}\left(\mathrm{La}_{1-x} \mathrm{Sr}_{x} \mathrm{MnO}_{3 \text {-delta }}\right)$ [10], $\mathrm{LSCFs}\left(\mathrm{La}_{1-x} \mathrm{Sr}_{x} \mathrm{Co}_{y} \mathrm{Fe}_{1-y} \mathrm{O}_{3 \text {-delta }}\right)$ [11-13] and many promising new candidates [14]. The current perovskite SOFC materials considered a toxic cobalt-free formula, such as $\mathrm{La}_{0.5} \mathrm{Sr}_{0.5} \mathrm{Fe}_{0.9} \mathrm{Nb}_{0.1} \mathrm{O}_{3}$-delta (LSFNb) by a simple sol-gel method [15] and $\mathrm{La}_{0.25} \mathrm{Sr}_{0.75} \mathrm{TiO}_{3}$ (LST) as the electrolyte in the super conduction [16].

Alternatively, the development of SOFC took advantage of mathematical models, via better understandings of reaction mechanisms of SOFC for its optimization in terms of cost, efficiency, and durability [17]. A few examples covered the current status of the development mathematical models and their focuses, such as the functionality of the direct internal reforming inside the SOFC system [18], a two-dimensional model on mass transport in the porous electrodes and fuel and air channels based on the lattice Boltzmann method (LBM) [19] and an anode-supported SOFC button cell [20]. Further, the more accurate three-dimensional mathematical models were developed to predict the key operating parameters on the performance of the planar type of SOFC and parasitic loads [3], optimized interconnect designs [21], different flow stack designs of the planar SOFC cells [22], the examination of the thermo-fluid reacting environment and local thermodynamic state in SOFC stacks [23]. A mathematical model was presented within the transmission network for dynamic stability analysis and control [24]. A few started to extract information on the restricted step in electrochemical properties of SOFC, such as effects of the electrolyte thickness and the operating temperature, but limited in investigations on the heat and mass transfer characteristics of SOFC [25]. A novel application of interior search optimizer was presented to define the necessary parameters to model SOFCs [26].

In summary, there were few explorations deep into the most critical parameters on electrode and electrolyte materials themselves, such as combining the ionic conductivity of electrode and electrolyte materials and the activation energy of electrochemical reactions. In searching for dominating factors restricting the overall performance and identification of critical parameters upon variable operational temperatures in a planar SOFC, a three-dimensional SOFC model was established based on COMSOL Multiphysics 5.4, COMSOL AB, Stockholm, Sweden. The numerical model couples mass transfer and electrochemical reactions. It served as a simulation platform to explore detailed reactant profiles on the multispecies mass transportations in gas channels and porous electrodes, ionic conductions, and electrochemical reactions, and further their impacts on the overall performance of SOFC. Based on this, the most significant and restricting parameters upon the development of the intermediate-temperature SOFC were critically investigated and identified. The study sketched views on the significance of switching between transportations and reactions of reactants in SOFCs, as well as assisting the material development in a precise way. 


\section{SOFC Modeling}

\subsection{Numerical Model}

The SOFC stacks consist of multiple cells, each of which has a dense electrolyte and porous oxidant and fuel electrodes with metallic interconnects that form gas channels and electronically and thermally connect the cells with each other. Within each unit cell of the SOFC stacks, oxidant and fuel domains are separated by the dense electrolyte through which oxygen ion conduction and heat conduction take place $[23,27]$.

Addressing effects of reactant transportations and electrochemical reactions on the performance of a SOFC, the establishment of the numerical model demands the integration of the heterogeneous thermo-electrochemistry, the momentum and the species and energy transport in the porous electrodes and through the electrolyte and interconnects, and the local thermodynamic state to elucidate the physical-chemical phenomena [23]. Given the repeating structure with a single interconnect separating and connecting two adjacent cells electrically in series, a single repeating unit was considered in numerical simulations to represent the entire stack [28].

A three-dimensional model for this single repeating planar SOFC was established and implemented based on the literature $[25,27,29,30]$, which is shown in Figure 1. The representative materials were used in this numerical model, involving the regular nickel/yttria-stabilized zirconia (Ni-YSZ) as the anode functional layer, the yttria-stabilized zirconia (YSZ) as the electrolyte, and the strontium-doped lanthanum manganite/yttria-stabilized zirconia (LSM-YSZ) as the cathode functional layer, and a metal interconnect. The computational domain makes up subdomains, including the anode-side and cathode-side interconnects, fuel and oxidant channels, anode and cathode electrodes, and the electrolyte, electrochemical reactions, as presented in the literature [3]. Considering the material development for the intermediate-temperature SOFC, 4 new electrolyte-based material systems were considered in this study, involving dysprosium- and tungsten-stabilized bismuth oxide (DWSB), $\mathrm{Er}_{2} \mathrm{O}_{3}$-stabilized $\mathrm{Bi}_{2} \mathrm{O}_{3}\left(\mathrm{Er}_{0.2} \mathrm{Bi}_{0.8} \mathrm{O}_{1.5}, \mathrm{ESB}\right)$, development of $\mathrm{Sm}_{0.075} \mathrm{Nd}_{0.075} \mathrm{Ce}_{0.85} \mathrm{O}_{2-\delta}$ (SNDC), and Gadolinium-doped ceria $\left(\mathrm{Ce}_{0.9} \mathrm{Gd}_{0.1} \mathrm{O}_{2-\delta}, \mathrm{GDC}\right)$ [1]. The sensitivity studies were carried out via variations of the ionic conductivity by $900 \%, 400 \%$, and $100 \%$, and the activation energy by $10 \%$.

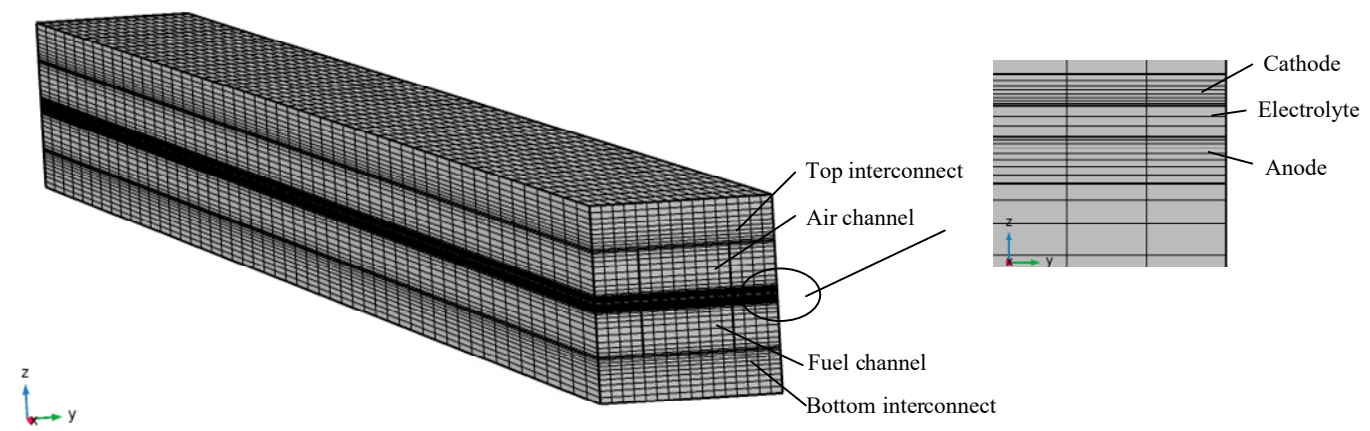

Figure 1. Three-dimensional model for the planar SOFC.

The geometric and physical model parameters are listed in Table 1. The counter flow configuration was adopted for the oxidant and fuel in the gas channels. Both gas mixtures of the oxidant and fuel are treated as an ideal gas, and the flow is laminar due to the low Reynolds number in the numerical calculations. The gas diffusion layers (GDLs) were made of isotropic and homogeneous porous materials, and isothermal conditions were assumed in the modeling [3]. Equations for ion, electron, momentum, gas-phase species transport, reactant electrochemical reactions were solved simultaneously and coupled to kinetics describing the overall SOFC electrode performances. The current model incorporated the mass, momentum, and charge balance, secondary current and Butler-Volmer equations. 
Table 1. Model parameters.

\begin{tabular}{ccc}
\hline Parameter & Symbol & Value \\
\hline Cell length & $\mathrm{L}_{\mathrm{cell}}$ & $100(\mathrm{~mm})$ \\
Gas channel height & $\mathrm{h}_{\mathrm{ch}}$ & $1(\mathrm{~mm})$ \\
Gas channel width & $\mathrm{w}_{\mathrm{ch}}$ & $2(\mathrm{~mm})$ \\
Interconnect height & $\mathrm{h}_{\mathrm{int}}$ & $2(\mathrm{~mm})$ \\
Width of single cell & $\mathrm{w}_{\mathrm{cell}}$ & $4(\mathrm{~mm})$ \\
Anode thickness & $\mathrm{t}_{\mathrm{a}}$ & $0.15(\mathrm{~mm})$ \\
Electrolyte thickness & $\mathrm{t}_{\mathrm{el}}$ & $0.1(\mathrm{~mm})$ \\
Cathode thickness & $\mathrm{t}_{\mathrm{c}}$ & $0.1(\mathrm{~mm})$ \\
Operating pressure & $\mathrm{p}_{0}$ & $1(\mathrm{~atm})$ \\
\hline
\end{tabular}

\subsection{Governing Equations}

\subsubsection{Electrochemical Model}

In this study, it was assumed that only fuel, hydrogen, participated in the electrochemical reaction, and oxygen can be reduced to its ionic form by electrons coming from the external load at the cathode, as follows

$$
\frac{1}{2} \mathrm{O}_{2}+2 \mathrm{e}^{-} \rightarrow \mathrm{O}^{2-}
$$

Hydrogen within the fuel chamber is firstly adsorbed at the anode, followed by the reaction with the oxygen ion at the anode electrolyte interface. This reaction results in two electrons and steam.

$$
\mathrm{H}_{2}+\mathrm{O}^{2-} \rightarrow \mathrm{H}_{2} \mathrm{O}+2 \mathrm{e}^{-}
$$

Transferring the current in fuel cells takes place through the transportation of electrons in the electrodes and the transportation of ions in the electrolyte. Electronic and ionic current densities are governed by the charge continuity equations associated with Ohm's law:

$$
\begin{aligned}
& \nabla \cdot \mathbf{i}_{\text {elec }}=\nabla \cdot\left(-\sigma_{\text {elec }}^{e f f} \nabla \varphi_{\text {elec }}\right)= \begin{cases}-S_{\text {current }} & \text { in anode functional layer } \\
S_{\text {current }} & \text { in cathode functional layer }\end{cases} \\
& \nabla \cdot \mathbf{i}_{\text {ion }}=\nabla \cdot\left(-\sigma_{\text {ion }}^{e f f} \nabla \varphi_{\text {ion }}\right)= \begin{cases}S_{\text {current }} & \text { in anode functional layer } \\
0 & \text { in electrolyte } \\
-S_{\text {current }} & \text { in cathode functional layer }\end{cases}
\end{aligned}
$$

where $\mathbf{i}_{\text {elec }}\left(\mathbf{i}_{\text {ion }}\right)$ is the electronic (ionic) current density vector, $\varphi_{\text {elec }}\left(\varphi_{\text {ion }}\right)$ is the electronic (ionic) potential, $S_{\text {current }}$ is the current source term, which appears in the porous electrode domain where the electrochemical reaction occurs. For the charge conservation, the source of electronic current is also the sink of ionic current. $\sigma_{\text {elec }}^{\text {eff }}\left(\sigma_{\text {ion }}^{\text {eff }}\right)$ is the effective electronic (ionic) conductivity of the porous electrode layer. Effective electronic and ionic conductivities are evaluated [23,31,32].

The actual potential and the open-circuit voltage can be expressed as:

$$
E=E^{O C V}-\left|\eta_{\text {act }}\right|-\eta_{\text {ohm }}-\eta_{\text {conc }}
$$

where $E^{\mathrm{OCV}}$ is the open-circuit voltage, $\eta_{\text {act }}$ is the activation overpotential, $\eta_{\text {ohm }}$ is the ohmic overpotential, and $\eta_{\text {conc }}$ is the concentration overpotential.

The Butler-Volmer charge transfer kinetics equation can be applied to describe the functional relation between the activation losses and charge transfer current density [33]:

$$
i_{l o c}=i_{0}\left[\exp \left(\alpha_{a} \frac{F \eta_{a c t}}{R T}\right)-\exp \left(-\alpha_{c} \frac{F \eta_{a c t}}{R T}\right)\right]
$$


where $i_{0}$ is the reference exchange current density $\left(\mathrm{A} \mathrm{m}^{-2}\right) . \quad \alpha_{a}$ is the anode transfer coefficient (dimensionless), and $\alpha_{c}$ is the cathode transfer coefficient (dimensionless). $F$ is Faraday constant, $9.65 \times 10^{4} \mathrm{C} \mathrm{mol}^{-1} \cdot i_{0}$ can be expressed by Equation (6)

$$
i_{0}=\frac{R T}{n_{e} F} k_{e}^{\prime \prime} \exp \left(\frac{-E_{a, e}}{R T}\right)
$$

where $k_{e}^{\prime \prime}$ is pre-exponential factor; $E_{a, e}$ is the activation energy.

\subsubsection{Mass and Momentum Transport}

The compressible Navier-Stokes equations govern the fluid flow in the gas channels, and the Brinkman equations can be employed for the porous GDEs:

$$
\begin{gathered}
\nabla \cdot(\rho \mathbf{u})=0 \\
\frac{\rho}{\varepsilon}(\mathbf{u} \cdot \nabla) \mathbf{u}=-\varepsilon \nabla p+\nabla\left[\mu\left(\left(\nabla \mathbf{u}+(\nabla \mathbf{u})^{T}\right)-\frac{2}{3}(\nabla \cdot \mathbf{u}) \mathbf{I}\right)\right]-\varepsilon \mathcal{K}^{-1} \mu \mathbf{u}+\varepsilon \mathbf{F}
\end{gathered}
$$

where $\mathbf{F}$ is the volume force vector, $p$ is the pressure, $\mathbf{u}$ is the velocity vector, $\mu$ is the viscosity of the fluid, and $\kappa$ is the permeability tensor of the porous medium.

\subsubsection{Species Transport}

The material transport can be described by Maxwell-Stefan's diffusion and convection equations, as shown below

$$
\nabla \cdot\left(\omega_{i} \rho \mathbf{u}-\rho \omega_{i} \sum_{j=1}^{n} D_{i j}\left(\nabla x_{j}+\left(x_{j}-\omega_{j}\right) \frac{\nabla p}{p}\right)\right)=0
$$

where $\omega_{i}$ is the mass fraction of species $i$, and $D_{i j}$ is the molecular diffusion coefficients.

\subsection{Boundary Conditions and Basic Model Parameters}

Based on experimental results of applied materials [29], voltages of the top and bottom interconnects were estimated to be an electrical potential from 0.5 to $0.9 \mathrm{~V}$ and an electrical ground, respectively. Span-wise side walls were considered as electric insulation. All the model parameters and operating conditions were primarily from the literature [29]. Unless stated otherwise, the following specific model parameters were used [34]. The inlet velocities and outlet pressures were pre-determined at both the oxidant channel and the fuel channels. The inlet velocity of oxidant was $3 \mathrm{~m} \mathrm{~s}^{-1}$ with a mass fraction ratio $\mathrm{O}_{2}$ and $\mathrm{N}_{2}$ of $0.15: 0.85$, and the inlet velocity of fuel was $0.4 \mathrm{~m} \mathrm{~s}^{-1}$ with a mass fraction ratio of $\mathrm{H}_{2}$ and $\mathrm{H}_{2} \mathrm{O}$ of 0.4:0.6. The pressure at the outlet was set to the ambient conditions, while the channel wall was set up to be a no-slip condition and the zero diffusive flux. The Butler-Volmer equations were coupled with the governing equations and provided the current densities at the triple-phase boundaries for given gas concentrations and activation overpotentials. Complete mesh consists of 47,200 domain elements for achieving the adaption, accuracy, and computational efficiency.

It's assumed that the cell operated at a temperature of $1073 \mathrm{~K}\left(800^{\circ} \mathrm{C}\right)$ with both fuel and oxidant at a pressure of $1 \mathrm{~atm}$. The viscosities of fuel and oxidant were $2.4320 \times 10^{-5}$ and $4.4574 \times 10^{-5} \mathrm{~Pa} \cdot \mathrm{s}$, respectively. The diffusion volumes for $\mathrm{H}_{2}, \mathrm{H}_{2} \mathrm{O}, \mathrm{O}_{2}$, and $\mathrm{N}_{2}$ were $7.07 \times 10^{-6}, 12.7 \times 10^{-6}, 16.6 \times 10^{-6}$, and $17.9 \times 10^{-6} \mathrm{~m}^{3} \mathrm{~mol}^{-1}$, respectively. The reference diffusivity $k_{d} 3.16 \times 10^{-8} \mathrm{~m}^{2} \mathrm{~s}^{-1}$, and the diffusion parameters for the transport phenomena were estimated at the temperature of $800{ }^{\circ} \mathrm{C}$. For both anode and cathode, the porosity was set at 0.34 , the tortuosity 3.8 , the pore size $5 \times 10^{-7}$, and the permeability $1.76 \times 10^{-11} \mathrm{~m}^{2}$. Electronic and ionic conductivities and the activation energy are considered to be functions of the temperature. The anode and cathode reference exchange current densities were 4637.4 $\mathrm{A} \mathrm{m}^{-2}$ and 1166.2 $\mathrm{A} \mathrm{m}^{-2}$ respectively. 
Upon varied temperatures, the temperature-dependent dynamic viscosity of gas species (fuels and oxidizer air) can be calculated based on Equation (11), and their mixture properties can be obtained based on their molar average as shown in Equation (12).

$$
\begin{gathered}
\mu_{i}=\sum_{i=0}^{6} a_{i}\left(\frac{T}{1000}\right)^{i} \\
\mu_{\text {mix }}=\sum x_{i} \mu_{i}
\end{gathered}
$$

where $a_{i}$ is the gas species dependent parameter referenced in [35], and $x_{i}$ is mole fraction of gas species i. $T$ is temperature.

\section{Results and Discussion}

\subsection{The Model Validation}

The numerical simulation was conducted to evaluate the effects of parameters on the thermo-fluidic-reaction characteristics of the unit cell stack of the SOFC, using the commercial finite element software COMSOL Multiphysics. The comparison of the performance curve determined a properly applied grid to efficiently reach accurate results.

The numerical simulations were initially carried out following the same cell designs and operating parameters in the published literature $[25,29]$. The numerical results on the cell voltage, power density, and their associated current densities based on our current model were compared to those of published experimental and numerical results, in Figure 2.

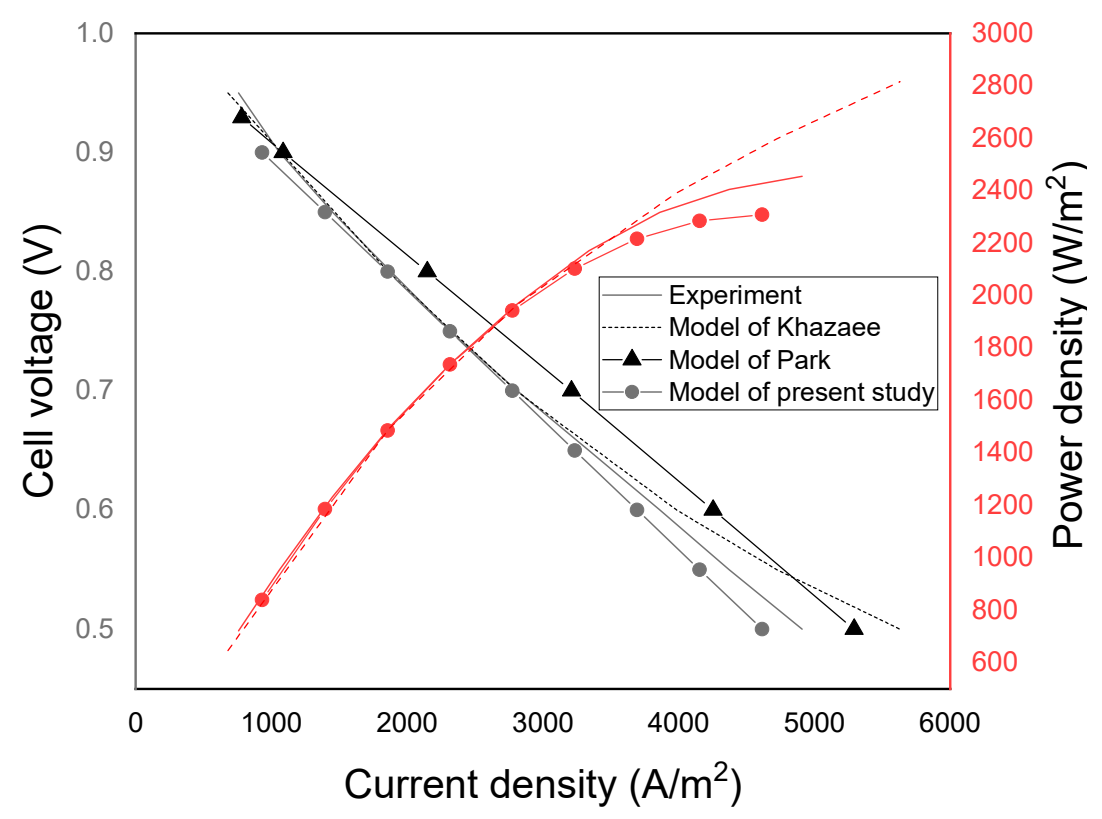

Figure 2. Comparison of the experimental and numerical results.

The errors between the present numerical results and the experimental results were less than $7 \%$, implying that the current model agrees well with both experimental and previously-published numerical results $[25,29]$. The minimal difference in the current model and experimental results was mainly derived from the assumption and simplification of models which has primarily been introduced in the literature [25], such as an ideal transport among multilayers of SOFC and diversified sources of physical parameters of the porous electrodes [36,37]. The accuracy of the simulation would be expected upon the future readiness of experimental material characterizations. 


\subsection{The Temperature-Dependence of the Regular YSZ Electrolyte (the Absolutely Electrolyte-Dominating Case)}

To realize the intermediate temperature operation of the SOFC, the significance of temperature effect on the performance of SOFC components was initially investigated, based on the established model with capability in the quantitative evaluation of all concerned parameters of SOFC. Taking the regular and most popular YSZ electrolyte as an example, the sensitivity of the YSZ electrolyte with the operation temperature can be calculated. It's assumed that major parameters on fuel and oxidize channels and electrodes, such as their velocity and constituents, were kept constant.

Figure 3a exhibited the numerical results on the temperature dependence of the cell voltage, the power density, and their associated current densities following a trend of temperatures of $800^{\circ} \mathrm{C}$, $700{ }^{\circ} \mathrm{C}$, and as low as $650^{\circ} \mathrm{C}$. The current density of the electrolyte for different temperatures was depicted Figure $3 \mathrm{~b}$ at an operating voltage of $0.8 \mathrm{~V}$.

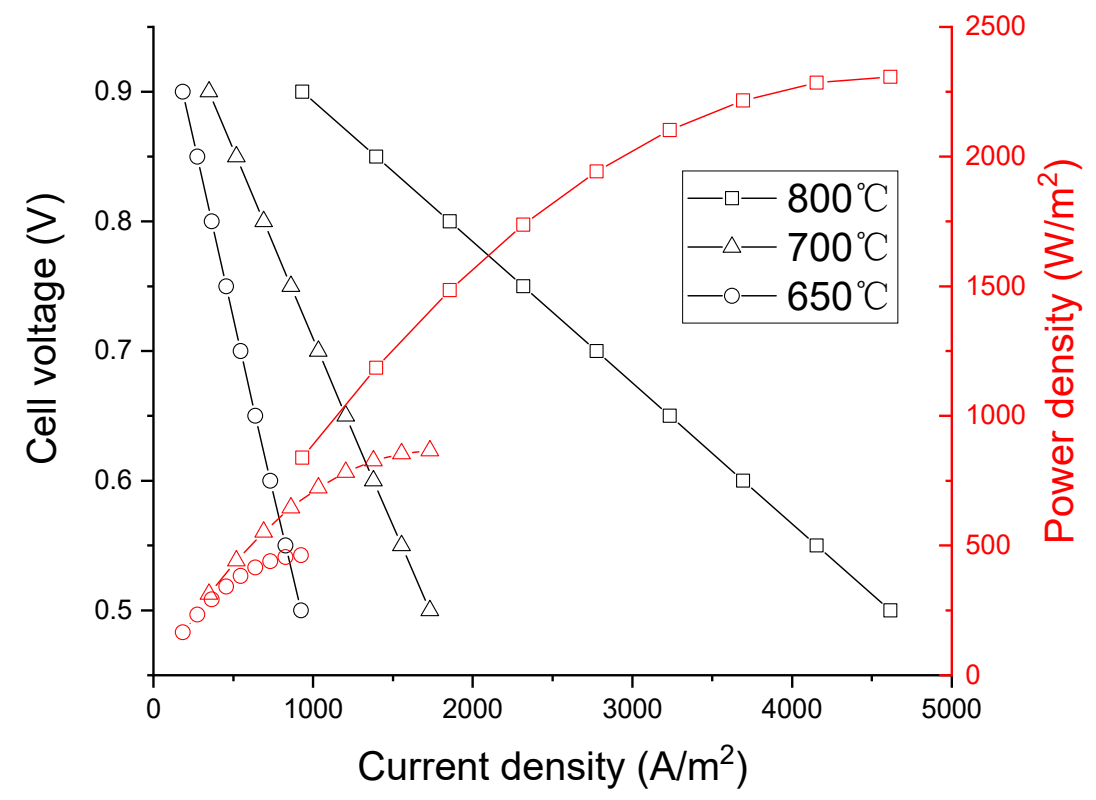

(a) Cell voltage and the power density

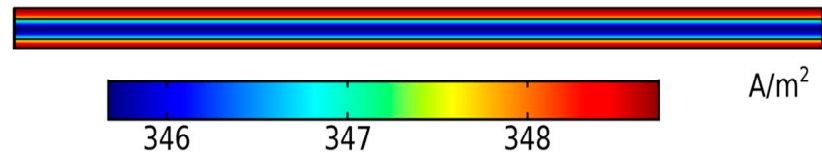

(1) $650^{\circ} \mathrm{C}$

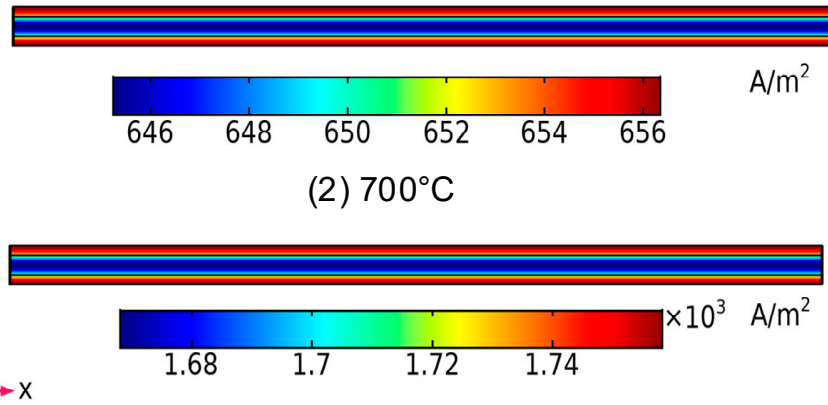

(3) $800^{\circ} \mathrm{C}$

(b) Current density distribution

Figure 3. Comparison between two cases with different operating temperatures. 
As shown in Figure 3a, the decrease of the operational temperatures from $800{ }^{\circ} \mathrm{C}$ to $700{ }^{\circ} \mathrm{C}$ and $650{ }^{\circ} \mathrm{C}$, the current density significantly dropped by $63 \%$ and $80 \%$ at a constant operational voltage, implying the dramatic diminution of the cell performance as a consequence of lowing operating temperature by only $100{ }^{\circ} \mathrm{C}$ and $150{ }^{\circ} \mathrm{C}$, respectively. Further investigation revealed the important temperature dependence of the ionic conductivity of the electrolyte, such as a $79 \%$ loss of the ionic conductivity in the applied YSZ electrolyte as a temperature dropping from $800{ }^{\circ} \mathrm{C}$ to $650{ }^{\circ} \mathrm{C}$. Meanwhile, for a similar reason, the reference exchange current density $i_{0}$ of both anode and cathode dropped by $93.3 \%$ and $92.9 \%$, respectively. In many anode-supported SOFC applications, a thinner electrolyte was usually applied at lower temperature operations to decrease its ohmic overpotential. But notably, the unexpected performance was still its major issues [5]. Considering a minimum thickness of about $10 \mathrm{~mm}$ of YSZ in terms of its acceptable structural strength, the limit to operating temperature can only be as low as $700{ }^{\circ} \mathrm{C}$ [1]. Therefore, further dropping to a desirable temperature as $650{ }^{\circ} \mathrm{C}$ unavoidably depended on the development of a new electrolyte with a higher ionic conductivity. It should be noticeable that the current designs of electrodes in the SOFC was exclusively the active-material-on-electrolyte. Therefore, the temperature-dependent properties of electrolytes had great impacts on the electrode performance in such structured SOFC.

\subsection{The Temperature-Dependent Ionic Conductivity in Novel Electrolytes}

The ion conductivity in the electrolyte was specifically noticed on its crucial influence on the overall conductivity, considering that it's significantly lower than the electric conductivities by several orders of magnitude. This was especially true when they were applied in the intermediate-temperature SOFC. Under this inspiration, a new group of novel electrolyte materials were developed, leading both the increase of their ionic conductivity as well as further understandings of the fundamental oxide ion conduction mechanisms. Various electrolytes, alternative to YSZ, have been prepared and investigated [38], mainly two groups involving aliovalent-doped ceria and isovalent-cation-stabilized bismuth oxides, which were particularly attractive in their superior ionic conductivity and thus applicable in the SOFC at the intermediate temperatures. Among them, dysprosium- and tungsten-stabilized bismuth oxide (DWSB) has a closer inherent structure to the pure $\mathrm{d}-\mathrm{Bi}_{2} \mathrm{O}_{3}$. Both lattice parameter and conductivity linearly extrapolated with the total dopant concentration in the pure $\mathrm{d}-\mathrm{Bi}_{2} \mathrm{O}_{3}$, resulting in its ability to stabilize d-phase at its lower dopant concentration, and thus achieving higher conductivity [39]. The singly doped $\mathrm{Bi}_{2} \mathrm{O}_{3} \mathrm{~s}, \mathrm{Er}_{2} \mathrm{O}_{3}$-stabilized $\mathrm{Bi}_{2} \mathrm{O}_{3}\left(\mathrm{Er}_{0.2} \mathrm{Bi}_{0.8} \mathrm{O}_{1.5}, \mathrm{ESB}\right)$ was known to have the highest oxygen ion conductivity in its lowest dopant $\left(\mathrm{Er}^{3+}\right)$ concentration required to achieve the cubic $\delta$-phase stabilization [40]. Gadolinium-doped ceria $\left(\mathrm{Ce}_{0.9} \mathrm{Gd}_{0.1} \mathrm{O}_{2-\delta}, \mathrm{GDC}\right)$ [41] has a cubic structure and a density of around $7.2 \mathrm{~g} \mathrm{~cm}^{-3}$ in its oxidized form. It is one of a class of ceria-doped electrolytes with higher ionic conductivity and lower operating temperatures $\left(<700^{\circ} \mathrm{C}\right)$. Optimization of dopant concentration in the $\mathrm{Sm}_{\mathrm{x} / 2} \mathrm{Nd}_{\mathrm{x} / 2} \mathrm{Ce}_{1-\mathrm{x}} \mathrm{O}_{2-\delta}$ system resulted in the development of $\mathrm{Sm}_{0.075} \mathrm{Nd}_{0.075} \mathrm{Ce}_{0.85} \mathrm{O}_{2-\delta}$ (SNDC), which exhibited a higher grain ionic conductivity than that of GDC in air [42]. Table 2 listed temperature-dependent ionic conductivity properties of these 4 novel electrolytes in open literature [1], and YSZ as a referenced electrolyte.

Table 2. Ionic conductivities of different electrolytes.

\begin{tabular}{cccccc}
\hline Electrolyte & DWSB & ESB & SNDC & GDC & YSZ \\
\hline$\sigma_{\mathrm{el}}$ at $650{ }^{\circ} \mathrm{C}, \mathrm{S} / \mathrm{m}$ & 43.708 & 24.551 & 3.734 & 2.765 & 0.608 \\
$\sigma_{\mathrm{el}}$ at $700{ }^{\circ} \mathrm{C}, \mathrm{S} / \mathrm{m}$ & 58.417 & 34.459 & 5.522 & 3.941 & 1.023 \\
\hline
\end{tabular}

To evaluate the intermediate temperature operation of the SOFC with these new electrolytes, the overall performance and current densities for the different electrolytes were discussed. In the process, Except for the electrolyte, the geometric and other physical model parameters were the same as depicted in Section 2.1. Figure 4 revealed the expected increase in the overall current density of SOFC upon the improvement of the ionic conductivity in applied electrolytes at the same operational 
voltage, but without consideration of activation energy variation, there was no straightforward linearity dependence between the overall current density of SOFC and the ionic conductivity the electrolyte. Figure 5 exhibited the current densities of the different electrolytes when different electrolytes were applied at an operating voltage of $0.8 \mathrm{~V}$ and $700^{\circ} \mathrm{C}$.

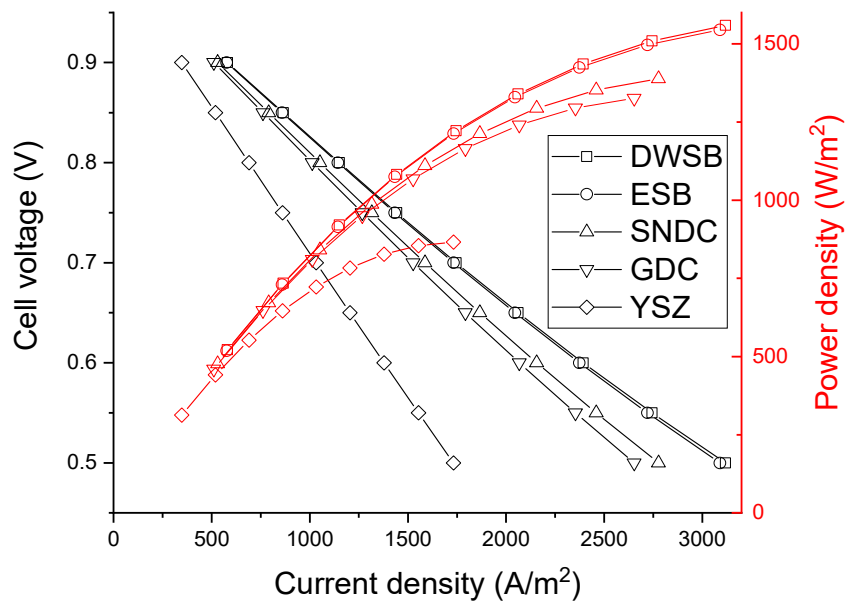

(a) Operating temperature of $700{ }^{\circ} \mathrm{C}$

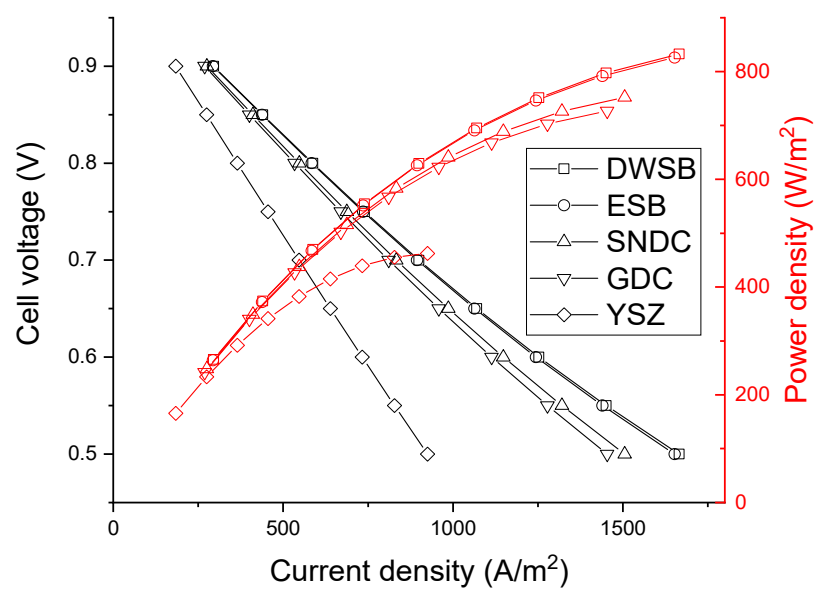

(b) Operating temperature of $650{ }^{\circ} \mathrm{C}$

Figure 4. Performance of SOFC with different electrolytes at two operating temperatures.

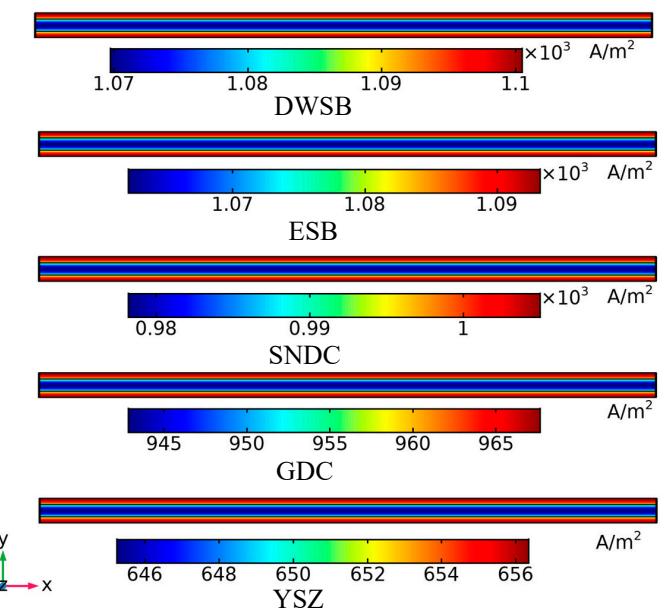

Figure 5. Current density distributions of the different electrolytes. 
For example, in a case of $700{ }^{\circ} \mathrm{C}$ and $0.8 \mathrm{~V}$ operational voltage, the correspondent current density were only 1.67, 1.66, 1.52, 1.47 times of that of YSZ as an electrolyte, versus aforementioned ionic conductivities of 4 electrolytes (DWSB, ESB, SNDC, GDC) at their 71.88, 40.38, 6.14, and 4.55 times of that of YSZ. This implied the improvement of the current density of the SOFC was very limited upon the significant improvement in ionic conductivity of applied electrolytes. Notably, the ionic conductivity of DWSB was 14.8 times higher than that of GDC, versus the difference in the current density by only $13.6 \%$. This was also true when the operational temperature further dropped to $650{ }^{\circ} \mathrm{C}$. The most significant improvement in the SOFC performance, in terms of the current density, was when the switch from YSZ to GDC electrolytes, implying that the significant impact of the ionic conductivity of the electrolyte only when it was lower. And the further improvement of the ionic conductivity should not contribute any more benefits of the SOFC performance in the current specific situation. This was a sign of the transition of restriction steps of the overall electrochemical process inside SOFC.

\subsection{The Transition of the Dominating Factor}

Actually, both the ohmic overpotential and the activation overpotential contributed to the overall SOFC performance. The ohmic overpotential consists of all electric conductions including the aforementioned ionic conductivity and electronic conductivity. The activation overpotential was mainly relative to electrochemical reactions of reactants in electrodes of SOFC. At a constant temperature and same electrode materials, the activation overpotential can be regarded as equivalent, and thus the only ohmic overpotential can be focused. The Ohmic overpotential $\left(\eta_{\mathrm{ohm}}\right)$ is proportional to the current density $i$ as given by:

$$
\eta_{\mathrm{ohm}}=i R_{\mathrm{ohm}}
$$

where $R_{\mathrm{ohm}}$ is the overall internal resistance of the cell that can be estimated from the effective distance between the cell components coupled with conductivity data, as given by $[43,44]$ :

$$
R_{\text {ohm }}=\frac{\tau_{\text {anode }}}{\sigma_{\text {anode }}}+\frac{\tau_{\text {elctrolyte }}}{\sigma_{\text {elctrolyte }}}+\frac{\tau_{\text {cathode }}}{\sigma_{\text {cathode }}}+\frac{\tau_{\text {interconnect }}}{\sigma_{\text {interconnect }}}
$$

where $\tau$ is the thickness of each cell component, and $\sigma_{\text {anode, }} \sigma_{\text {cathode, }}$ and $\sigma_{\text {interconnect }}$ are the electronic conductivity of the anode, cathode and interconnect, and $\sigma_{\text {electrolyte }}$ is the ionic conductivity of the electrolyte.

In our current calculations, the electronic and ionic current densities were both governed by the charge continuity equations involving both the ionic conducting phase and the electronic conducting phase. Thus, the analysis on the Ohmic overpotential for the calculation of the internal resistance was based on Equation (14). Table 3 lists the ratio for each selected electrolyte. This ratio was defined as a proportion between the electrical resistance of the applied electrolyte and the overall internal resistance of the cell unit (involving electrical resistance of the applied interconnect). The larger the ratio, the greater the contribution of electrical resistance of the applied electrolyte toward the overall internal resistance of the cell unit.

Table 3. The proportion of electrical resistances for different electrolytes.

\begin{tabular}{cccccc}
\hline Operating Temperature & DWSB & ESB & SNDC & GDC & YSZ \\
\hline $650{ }^{\circ} \mathrm{C}$ & $10.4 \%$ & $17.1 \%$ & $57.6 \%$ & $64.7 \%$ & $89.3 \%$ \\
$700{ }^{\circ} \mathrm{C}$ & $8.1 \%$ & $12.9 \%$ & $48.1 \%$ & $56.5 \%$ & $83.4 \%$ \\
\hline
\end{tabular}

Table 3 indicated that the YSZ electrolyte has a large aforementioned ratio, and lower operational temperature lead to a larger ratio, such as $89.3 \%$ at $650{ }^{\circ} \mathrm{C}$ and $83.4 \%$ at $700{ }^{\circ} \mathrm{C}$, which both were over $80 \%$. Under this case, the improvement in the ionic conductivity of the electrolyte should be significant in the enhancement of the SOFC performance, just as that shown in Section 3.3 when the regular YSZ electrolyte was switched with the GDC electrolyte. However, this trend was not continued 
as the ratio dropped to about $60 \%$, as referring to the case of the switch from the GDC electrolyte to either SNDC, ESB, and DWSB, respectively, which corresponded to less effective improvement of the SOFC performance. This coincided with ratios of other three advanced electrolytes with excellent ionic conductivities, such as ratios of the electrical resistance in the internal resistance of the cell dropped to $64.7 \%, 57.6 \%, 17.1 \%, 10.4 \%$ at $650{ }^{\circ} \mathrm{C}$ for GDC, SNDC, ESB, and DWSB, respectively. These ratios were further dropped upon temperature toward $700{ }^{\circ} \mathrm{C}$. The lower the operational temperature, the higher critical ratio of the electrical resistance of the electrolyte in the overall internal resistance of the cell. Alternatively, the cell voltage and the power density with their associated current densities can be calculated, if the increase of the ionic conductivity of the YSZ electrolyte can be assumed to be 2, 5, and 10 times of the ionic conductivity of the regular YSZ electrolyte $\left(2.2669 \mathrm{~S} \mathrm{~m}^{-1}\right)$. Figure 6 exhibits the comparison results on the cell voltage and the power density with their associated current densities in these cases. It was found the current density was enhanced by only $57.8 \%, 48.3 \%$, and $25.6 \%$ at the same cell voltage, noticing that the ionic conductivity has been greatly increased by $900 \%, 400 \%$, and $100 \%$. A similar result was obtained, especially the move of $400 \%$ to $900 \%$ in the ionic conductivity to validate the critical value of the ratio of the electrical resistance.

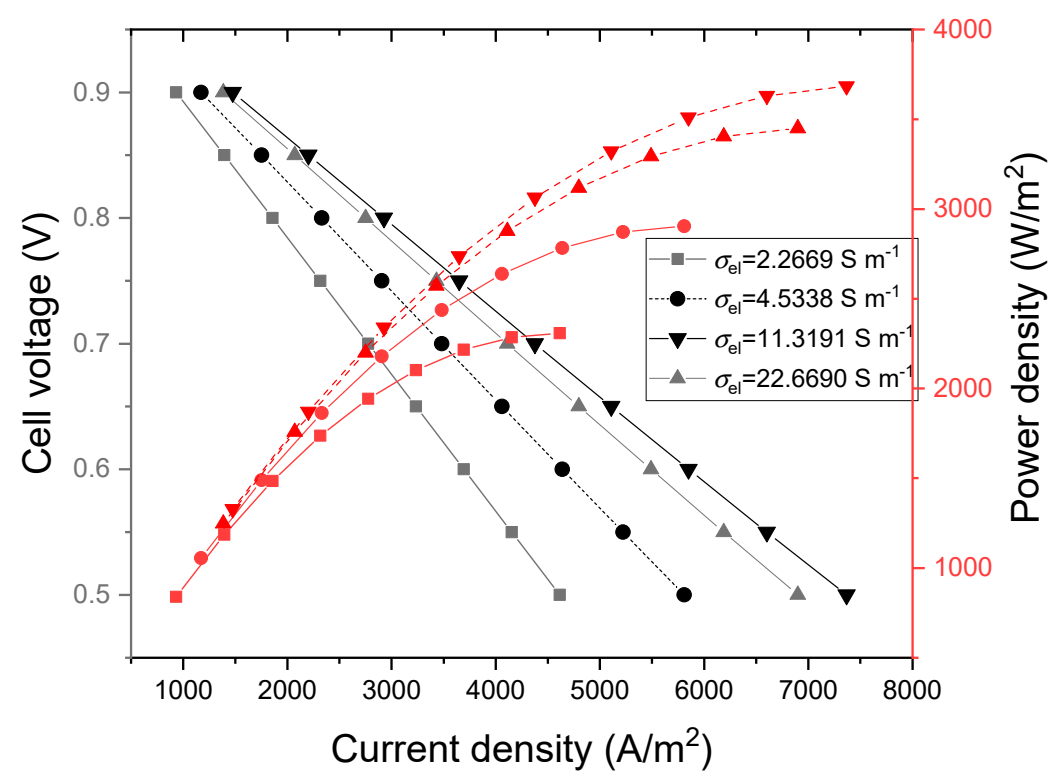

Figure 6. Comparison among cases with different ionic conductivities.

There indeed existed a critical value of the addressed ratio, referring to the electrical resistance of the electrolyte in the overall internal resistance of the cell. The corresponding enhancement of the SOFC performance to the improvement only occurred when the ionic conductivity of electrolytes accounted for a substantial part of the electrical resistance. If the increase of ionic conductivity of the YSZ substrate in anode and cathode are considered, the current density can be increased by a further $15 \%, 43 \%$, and $64 \%$, respectively, corresponding to assuming ionic conductivity of YSZ 2, 5, and 10 times greater. This well explained the mechanism on the effect of the operational temperature on the overall performance of SOFC. This would be a moment on the switch of restriction steps of the electrochemical process in the SOFC.

\subsection{The Switch of the Restriction Steps of Electrochemical Reactions in SOFC}

Since the switch of the restriction steps of electrochemical reactions in the SOFC was caused by the temperature, other parameters of temperature dependence were further investigated. It was noticed that the activation overpotential became significantly lower to cause a cell voltage drop when the operating temperature decreased (such as $650{ }^{\circ} \mathrm{C}$ ), although it was insignificantly small at higher temperatures, such as $800{ }^{\circ} \mathrm{C}$ [5]. The activation overpotential ( $\left.\eta_{\text {act }}\right)$ refers to the restriction effect of chemisorption and electrochemical activation of gas reactants on electrode materials. The higher the 
activation overpotential, the lower reaction rates of electrochemical reactions in SOFC. This implied that the drastic degradation of the cell performance at the decrease of operating temperatures can also be caused by an increase in not only the ohmic overpotential, also the activation overpotential. The former seemed less significant to restrict SOFC performance than the latter.

The generally-accepted Butler-Volmer equation (Equation (6)) was applied to describe the activation overpotential in this study, and the relevant reference exchange current density $i_{0}$ was defined by Equation (7), in which the temperature-dependent $i_{0}$ was solely attributed to the activation energy. It's noticeable that the activation energy of the regular $800{ }^{\circ} \mathrm{C}$-adaptable electrode materials increases upon the operational temperature decreases. The activation energy was assumed to be both a $10 \%$ increase upon the operational temperatures dropping to $700^{\circ} \mathrm{C}$ and $650{ }^{\circ} \mathrm{C}$, respectively using YSZ as the electrolyte. The calculated $i_{0}$ were found to be $82.3 \%$ and $81.6 \%$ lower in the anode and cathode, respectively, and $83.9 \%$ and $83.2 \%$, respectively at further lower to be $650{ }^{\circ} \mathrm{C}$. The increase of the activation energy by only $10 \%$ significantly decreased $i_{0}$. Table 4 lists the calculated overall cell current density when temperatures were at $700{ }^{\circ} \mathrm{C}$ and $650{ }^{\circ} \mathrm{C}$ at the cell voltage of $0.8 \mathrm{~V}$, covering five different electrolytes. For the regular YSZ, the drops of the overall cell current density were $42.8 \%$ and $49 \%$ at temperatures of $700{ }^{\circ} \mathrm{C}$ and $650{ }^{\circ} \mathrm{C}$, respectively, almost $50 \%$ lower. Switching to GDC electrolyte, of which ionic conductivity was several times higher than that of YSZ at the same temperature, only $52.1 \%$ and $58.4 \%$ of the overall cell current density dropped. This trend was followed by the SNDC, ESB, and DWSB, where ionic conductivities were much higher than that of YSZ. It implied the electrochemical reactions dominated the overall SOFC performance, rather than the ionic conduction. The activation energy of electrode materials exhibited more sensitivity to the temperature than the ionic conductivity of electrolyte to the temperature.

Table 4. The cell current density versus the change of the activation energy (by $10 \%$ increase of the activation energy) with different electrolytes.

\begin{tabular}{cccccc}
\hline Electrolyte & DWSB & ESB & SNDC & GDC & YSZ \\
\hline Decrease ratio of current density, $700^{\circ} \mathrm{C}$ & $\sim 55.5 \%$ & $\sim 55.3 \%$ & $\sim 53.1 \%$ & $\sim 52.1 \%$ & $\sim 42.8 \%$ \\
Decrease ratio of current density, $650^{\circ} \mathrm{C}$ & $\sim 60.9 \%$ & $\sim 60.8 \%$ & $\sim 59.1 \%$ & $\sim 58.4 \%$ & $\sim 49.0 \%$ \\
\hline
\end{tabular}

It's important to decrease the activation energy of the electrode material during the development of novel advanced materials. A similar calculation was conducted, but the activation energy was decreased by $10 \%$ upon the decrease of the temperature, to show its significance of the development of currently advanced electrode materials. Table 5 exhibits the increased multiple of calculated reference exchange current density $i_{0}$ versus the change of the activation energy, referenced by $i_{0}$ at the true activation energy. Table 6 exhibits the increased proportion of current density of SOFC cell unit when a $10 \%$ decrease of the activation energy at an operating voltage of $0.8 \mathrm{~V}$.

Table 5. The calculated reference exchange current density $i_{0}$ versus the change of the activation energy (by $10 \%$ decrease of the activation energy).

\begin{tabular}{cccc}
\hline Operational Temperature, ${ }^{\circ} \mathrm{C}$ & $\mathbf{8 0 0}{ }^{\circ} \mathbf{C}$ & $\mathbf{7 0 0}^{\circ} \mathbf{C}$ & $\mathbf{6 5 0}^{\circ} \mathbf{C}$ \\
\hline The multiple of $i_{0}$ in the anode, referenced by $i_{0}$ at its true activation energy & 3.80 & 4.64 & 5.20 \\
\hline The multiple of $i_{0}$ in the cathode, referenced by $i_{0}$ at the true activation energy & 3.64 & 4.44 & 4.96 \\
\hline
\end{tabular}

Table 6. The cell current density versus the change of the activation energy (by $10 \%$ decrease of the activation energy) with different electrolytes.

\begin{tabular}{cccccc}
\hline Electrolyte & DWSB & ESB & SNDC & GDC & YSZ \\
\hline Increase ratio of current density, $700{ }^{\circ} \mathrm{C}$ & $\sim 101 \%$ & $\sim 99 \%$ & $\sim 85 \%$ & $\sim 80 \%$ & $\sim 43 \%$ \\
Increase ratio of current density, $650{ }^{\circ} \mathrm{C}$ & $\sim 127 \%$ & $\sim 125 \%$ & $\sim 108 \%$ & $\sim 103 \%$ & $\sim 54 \%$ \\
\hline
\end{tabular}


Table 5 indicates the significant impact of the activation energy on the reference exchange current density $i_{0}$. The increase of only $10 \%$ activation energy can increase $i_{0}$ in $380 \%, 464 \%$, and $520 \%$ at $800{ }^{\circ} \mathrm{C}, 700{ }^{\circ} \mathrm{C}$ and $650{ }^{\circ} \mathrm{C}$ in anode, and similarly $364 \%, 444 \%$, and $496 \%$ in the cathode. Furthermore, it was interested to find the decrease of the activation energy by only $10 \%$ increased the overall cell current density by $27 \%, 43 \%$, and $54 \%$ at temperatures of $800{ }^{\circ} \mathrm{C}, 700^{\circ} \mathrm{C}$, and $650{ }^{\circ} \mathrm{C}$, respectively, in the case of the regular YSZ electrolyte material at the same cell voltage. Similar to the case of the ionic conductivity, the change of the overall current density was not linearly proportional to the temperature of the SOFC. Table 6 indicated that switching to other electrolytes with increased ionic conductivities, the cell current density seemed not to change this trend, either. Moreover, the cell current density was independent from the variation of electrolytes, which was solely attributed to the activation energy of electrochemical reactions.

\section{Conclusions}

This study established a three-dimensional SOFC model based on the Comsol software package, focusing on the identification of critical parameters upon variable operational temperatures in a planar SOFC. The numerical results were in good agreement with the available data in the literature, and accuracy and reliability of the numerical model were validated. The current studies specially addressed major aspects of restricting parameters upon the development of the intermediate-temperature SOFC.

In searching for dominating factors restricting the overall SOFC performance, the ionic conductivity of the electrolyte was primarily focused, which was critical not only as the electrolyte itself but also the substrates applied for electrodes. The temperature-dependent nature of the ionic conductivity of electrolyte materials was identified to be unavoidably concerned in the development of the intermediate-temperature SOFC, because the current density can be $63 \%$ and $80 \%$ decreases when the operational temperature dropped to the ideal $700{ }^{\circ} \mathrm{C}$ and $650{ }^{\circ} \mathrm{C}$ from the regular $800{ }^{\circ} \mathrm{C}$. However, the increase of the ionic conductivity of concerned materials was not linearly proportional to the current density of the SOFC. There identified a critical value on the ratio of electric resistance of the electrolyte in the overall internal resistance of the SOFC, above which the further increase in the ionic conductivity would not significantly improve the SOFC performance in terms of current density at a constant voltage.

The lower the operational temperature, the higher critical ratio of the electrical resistance in the overall internal resistance of the cell. The minimal decrease in the activation energy during the development of intermediate electrode materials can significantly enhance the overall SOFC cell performance, implied the restricting step in the whole electrochemical reactions in SOFC was the activation energy of electrode material. Considering the development trend toward the intermediate temperature SOFC, advanced electrode material with the decreased activation energy should be primarily focused. It's all about the switch of restriction of steps in the whole electrochemical reactions in SOFC. A simulation model exhibited the potentials to assist the material development in a precise way.

Author Contributions: Conceptualization, Y.C. and K.W.; Data curation, F.G.; Formal analysis, Funding acquisition, K.W. and Y.C.; Writing-original draft, B.A. and Y.W.; Writing-review \& editing, Y.W. and Y.C.; Project administration, K.W. All authors have read and agreed to the published version of the manuscript.

Funding: This research was funded by the National Key Research and Development program of China-Intergovernmental International Scientific and Technological Innovation Cooperation [grant number 2017YFE0105500], the National Natural Science Foundation of China [grant numbers 51776190,21676001].

Conflicts of Interest: The authors declare no conflict of interest. 


\section{References}

1. Wachsman, E.D.; Lee, K.T. Lowering the Temperature of Solid Oxide Fuel Cells. Science 2011, 334, 935-939. [CrossRef]

2. Tapan, N.A.; Yildiz, O. Electrochemical Performance of Low Pt and Ru Loaded Fe-Ni Bimetallics as an Anode Electrode in Direct Ethanol Fuel Cells. Int. J. Chem. React. Eng. 2010, 8, 29. [CrossRef]

3. Raj, A.; Sasmito, A.P.; Shamim, T. Numerical investigation of the effect of operating parameters on a planar solid oxide fuel cell. Energy Convers. Manag. 2015, 90, 138-145. [CrossRef]

4. Dogu, D.; Sohn, H.; Bhattacharya, S.; Cornelius, C.; Ozkan, U.S. Using Volatile Organic Compounds in Waste Streams as Fuel. Int. J. Chem. React. Eng. 2019, 17, 20180252. [CrossRef]

5. Patcharavorachot, Y.; Arpornwichanop, A.; Chuachuensuk, A. Electrochemical study of a planar solid oxide fuel cell: Role of support structures. J. Power Sources 2008, 177, 254-261. [CrossRef]

6. Lee, Y.; Park, J.; Yu, W.; Tanveer, W.H.; Lee, Y.H.; Cho, G.Y.; Park, T.; Zheng, C.; Lee, W.; Cha, S.W. Nickel-based bilayer thin-film anodes for low-temperature solid oxide fuel cells. Energy 2018, 161, 1133-1138. [CrossRef]

7. Liu, J.; Tu, T.; Peng, K. Preparation and properties of LSB-doped GDC electrolytes for intermediate temperature solid oxide fuel cells. Ionics 2018, 24, 3543-3554. [CrossRef]

8. Corbel, G.; Mestiri, S.; Lacorre, P. Physicochemical compatibility of CGO fluorite, LSM and LSCF perovskite electrode materials with $\mathrm{La}_{2} \mathrm{Mo}_{2} \mathrm{O}_{9}$ fast oxide-ion conductor. Solid State Sci. 2005, 7, 1216-1224. [CrossRef]

9. Goodenough, J.B. Theory of the Role of Covalence in the Perovskite-Type Manganites [La, $\mathrm{M}(\mathrm{II})] \mathrm{MnO}$. Phys. Rev. 1955, 100, 564-573. [CrossRef]

10. Casey, P.; Barker, D.; Hayward, M. Charge and structural ordering in the brownmillerite phases: $\mathrm{La}_{1-\mathrm{x}} \mathrm{Sr}_{\mathrm{x}} \mathrm{MnO}_{2.5}(0.2<\mathrm{x}<0.4)$. J. Solid State Chem. 2006, 179, 1375-1382.

11. Świerczek, K.; Dabrowski, B.; Suescun, L.; Kolesnik, S. Crystal structure and magnetic properties of high-oxygen pressure annealed $\mathrm{Sr}_{1-\mathrm{x}} \mathrm{La}_{\mathrm{x}} \mathrm{Co}_{0.5} \mathrm{Fe}_{0.5} \mathrm{O}_{3-\delta}(0 \leq \mathrm{x} \leq 0.5)$. J. Solid State Chem. 2009, 182, 280-288. [CrossRef]

12. Baqué, L.; Caneiro, A.; Moreno, M.S.; Serquis, A. High performance nanostructured IT-SOFC cathodes prepared by novel chemical method. Electrochem. Commun. 2008, 10, 1905-1908. [CrossRef]

13. Hodges, J.P.; Short, S.; Jorgensen, J.D.; Xiong, X.; Dabrowski, B.; Mini, S.M.; Kimball, C.W. Evolution of Oxygen-Vacancy Ordered Crystal Structures in the Perovskite Series $\operatorname{Sr}_{n} \mathrm{Fe}_{n} \mathrm{O}_{3 n-1}(\mathrm{n}=2,4,8$, and $\infty$ ), and the Relationship to Electronic and Magnetic Properties. J. Solid State Chem. 2000, 151, 190-209. [CrossRef]

14. Molenda, J.; Świerczek, K.; Zając, W. Functional materials for the IT-SOFC. J. Power Sources 2007, 173, 657-670. [CrossRef]

15. Bian, L.Z.; Duan, C.C.; Wang, L.J.; Zhu, L.Z.; O’Hayre, R.; Chou, K.C. Electrochemical performance and stability of $\mathrm{La}_{0.5} \mathrm{Sr}_{0.5} \mathrm{Fe}_{0.9} \mathrm{Nb}_{0.1} \mathrm{O}_{3 \text {-delta }}$ symmetric electrode for solid oxide fuel cells. J. Power Sources 2018, 399, 398-405. [CrossRef]

16. Chen, G.; Zhu, B.; Deng, H.; Luo, Y.; Sun, W.; Liu, H.; Zhang, W.; Wang, X.; Qian, Y.; Hu, X.; et al. Advanced Fuel Cell Based on Perovskite $\mathrm{La}_{-} \mathrm{SrTiO}_{3}$ Semiconductor as the Electrolyte with Superoxide-Ion Conduction. ACS Appl. Mater. Interfaces 2018, 10, 33179-33186. [CrossRef]

17. Hajimolana, S.A.; Hussain, M.A.; Daud, W.M.A.W.; Soroush, M.; Shamiri, A. Mathematical modeling of solid oxide fuel cells: A review. Renew. Sustain. Energy Rev. 2011, 15, 1893-1917. [CrossRef]

18. Tseronis, K.; Fragkopoulos, I.S.; Bonis, I.; Theodoropoulos, C. Detailed Multi-dimensional Modeling of Direct Internal Reforming Solid Oxide Fuel Cells. Fuel Cells 2016, 16, 294-312. [CrossRef]

19. Yahya, A.; Rabhi, R.; Dhahri, H.; Slimi, K. Numerical simulation of heat and mass transfer in solid oxide fuel cell in presence of magnet particles deposited in cathode side. Appl. Phys. A Mater. 2018, 124, 464. [CrossRef]

20. Barzi, Y.M.; Raoufi, A.; Lari, H. Performance analysis of a SOFC button cell using a CFD model. Int. J. Hydrogen Energy 2010, 35, 9468-9478. [CrossRef]

21. Zeng, S.M.; Zhang, X.Q.; Chen, J.S.; Li, T.S.; Andersson, M. Modeling of solid oxide fuel cells with optimized interconnect designs. Int. J. Heat Mass Transf. 2018, 125, 506-514. [CrossRef]

22. Liu, S.; Kong, W.; Lin, Z. Three-dimensional modeling of planar solid oxide fuel cells and the rib design optimization. J. Power Sources 2009, 194, 854-863. [CrossRef]

23. Lee, S.; Kim, H.; Yoon, K.J.; Son, J.W.; Lee, J.H.; Kim, B.K.; Choi, W.; Hong, J. The effect of fuel utilization on heat and mass transfer within solid oxide fuel cells examined by three-dimensional numerical simulations. Int. J. Heat Mass Transf. 2016, 97, 77-93. [CrossRef] 
24. Safari, A.; Shahsavari, H.; Salehi, J. A mathematical model of SOFC power plant for dynamic simulation of multi-machine power systems. Energy 2018, 149, 397-413. [CrossRef]

25. Park, J.M.; Kim, D.Y.; Baek, J.D.; Yoon, Y.J.; Su, P.C.; Lee, S.H. Effect of Electrolyte Thickness on Electrochemical Reactions and Thermo-Fluidic Characteristics inside a SOFC Unit Cell. Energies 2018, 11, 473. [CrossRef]

26. El-Hay, E.A.; El-Hameed, M.A.; El-Fergany, A.A. Optimized Parameters of SOFC for steady state and transient simulations using interior search algorithm. Energy 2019, 166, 451-461. [CrossRef]

27. Yakabe, H.; Ogiwara, T.; Hishinuma, M.; Yasuda, I. 3-D model calculation for planar SOFC. J. Power Sources 2001, 102, 144-154. [CrossRef]

28. Milewski, J.; Swirski, K.; Santarelli, M.; Leone, P. Advanced Methods of Solid Oxide Fuel Cell Modeling; Springer: London, UK, 2011.

29. Khazaee, I.; Rava, A. Numerical simulation of the performance of solid oxide fuel cell with different flow channel geometries. Energy 2017, 119, 235-244. [CrossRef]

30. Bhattacharya, D.; Mukhopadhyay, J.; Biswas, N.; Basu, R.N.; Das, P.K. Performance evaluation of different bipolar plate designs of 3D planar anode-supported SOFCs. Int. J. Heat Mass Transf. 2018, 123, 382-396. [CrossRef]

31. Kanno, D.; Shikazono, N.; Takagi, N.; Matsuzaki, K.; Kasagi, N. Evaluation of SOFC anode polarization simulation using three-dimensional microstructures reconstructed by FIB tomography. Electrochim. Acta 2011, 56, 4015-4021. [CrossRef]

32. Ferguson, J.R.; Fiard, J.M.; Herbin, R. Three-dimensional numerical simulation for various geometries of solid oxide fuel cells. J. Power Sources 1996, 58, 109-122. [CrossRef]

33. He, Z.; Li, H.; Birgersson, E. Reduced model for the planar solid oxide fuel cell. Comput. Chem. Eng. 2013, 52, 155-167. [CrossRef]

34. Liu, S.X.; Song, C.; Lin, Z.J. The effects of the interconnect rib contact resistance on the performance of planar solid oxide fuel cell stack and the rib design optimization. J. Power Sources 2008, 183, 214-225. [CrossRef]

35. Todd, B.; Young, J.B. Thermodynamic and transport properties of gases for use in solid oxide fuel cell modelling. J. Power Sources 2002, 110, 186-200. [CrossRef]

36. He, Z.; Birgersson, E.; Li, H. Reduced non-isothermal model for the planar solid oxide fuel cell and stack. Energy 2014, 70, 478-492. [CrossRef]

37. Janardhanan, V.M.; Deutschmann, O. CFD analysis of a solid oxide fuel cell with internal reforming: Coupled interactions of transport, heterogeneous catalysis and electrochemical processes. J. Power Sources 2006, 162, 1192-1202. [CrossRef]

38. Boivin, J.C.; Mairesse, G. Recent Material Developments in Fast Oxide Ion Conductors. Chem. Mater. 1998, 10, 2870-2888. [CrossRef]

39. Jung, D.W.; Duncan, K.L.; Wachsman, E.D. Effect of total dopant concentration and dopant ratio on conductivity of $\left(\mathrm{DyO}_{1.5}\right)_{\mathrm{x}}-\left(\mathrm{WO}_{3}\right)_{\mathrm{y}}-\left(\mathrm{BiO}_{1.5}\right)_{1-\mathrm{x}-\mathrm{y}}$. Acta Mater. 2010, 58, 355-363. [CrossRef]

40. Yun, B.-H.; Lee, C.-W.; Jeong, I.; Lee, K.T. Dramatic Enhancement of Long-Term Stability of Erbia-Stabilized Bismuth Oxides via Quadrivalent Hf Doping. Chem. Mater. 2017, 29, 10289-10293. [CrossRef]

41. Badwal, S.P.S.; Fini, D.; Ciacchi, F.T.; Munnings, C.; Kimpton, J.A.; Drennan, J. Structural and microstructural stability of ceria-Gadolinia electrolyte exposed to reducing environments of high temperature fuel cells. J. Mater. Chem. A 2013, 1, 10768-10782. [CrossRef]

42. Ahn, J.S.; Omar, S.; Yoon, H.; Nino, J.C.; Wachsman, E.D. Performance of anode-supported solid oxide fuel cell using novel ceria electrolyte. J. Power Sources 2010, 195, 2131-2135. [CrossRef]

43. Aguiar, P.; Adjiman, C.S.; Brandon, N.P. Anode-supported intermediate temperature direct internal reforming solid oxide fuel cell. I: Model-based steady-state performance. J. Power Sources 2004, 138, 120-136. [CrossRef]

44. Petruzzi, L.; Cocchi, S.; Fineschi, F. A global thermo-electrochemical model for SOFC systems design and engineering. J. Power Sources 2003, 118, 96-107. [CrossRef]

Publisher's Note: MDPI stays neutral with regard to jurisdictional claims in published maps and institutional affiliations. 